\title{
Editorial
}

\section{Número especial CIDI + CONGIC 2021}

Este número especial da Infodesign apresenta trabalhos selecionados do conjunto de artigos apresentados no $10^{\circ}$ Congresso Internacional de Design da Informação - CIDI 2021 e no $10^{\circ}$ Congresso Nacional de Iniciação Científica em Design da Informação - CONGIC 2021. Organizados pela Universidade Federal do Paraná em Curitiba, em contexto excepcional, devido à pandemia do coronavírus, os eventos foram realizados de forma totalmente online, de 18 a 22 de outubro de 2021.

A seleção dos artigos pautou-se na qualidade científica e reflete perspectivas contemporâneas de Design da Informação. As pesquisas versam sobre questões que vão desde análises tipográficas do início do século $\mathrm{xx}$ até contemporâneas, passando por análises de representações gráficas, de tendências e, destacando aspectos do design da informação em contextos educacionais, de saúde e inclusivos.

Em uma observação atenta a cultura material, em especial os livros, Ferraz e Lima investigam a dimensão semântica da tipografia nas capas de livros de temática feminista. As autoras versam sobre como a tipografia pode contribuir ou não para reforçar um senso comum da performatividade do gênero feminino.

Pereira e Farias discutem o pertencimento do repertório dos tipos utilizados em anúncios de oficinas tipográficas em periódicos produzidos por outras oficinas. A partir da análise de periódicos do início do século $\mathrm{xx}$, os autores destacam elementos da linguagem gráfica empregados na produção de artefatos que passaram a identificar as oficinas tipográficas.

Amstel traz à discussão um olhar sobre as tendências em mídias sociais e seu potencial de diferenciação social, por meio da análise de grafos gerados a partir de um corpus de tendências catalogado e classificado pelo autor e seus estudantes ao longo de três anos. Ao interpretar as visualizações à luz do diferencialismo materialistadialético o autor conclui que as tendências digitais se inclinam a manter o status quo.

Cadena, Dunes, França e Coutinho trazem um framework para analisar a organização gráfica na escrita a mão. As autoras apresentam o uso deste instrumento em três pesquisas distintas, trazendo contribuições sobre a prática da escrita a mão por estudantes.

As contribuições do design da informação na área da saúde têm se consolidado nos últimos anos, algumas demonstrações são a inclusão do eixo temático de saúde nesta edição. Neste sentido, o trabalho de Angari, Pontillo, Langella e Piscitelli relatam experiências promissoras, 
onde o design da informação atua como mediador facilitando a comunicação entre pesquisadores, médicos e pacientes.

Ainda no contexto de saúde e trazendo a pauta da inclusão Hammerschmidt e Spinillo analisam a legibilidade das tabelas nutricionais, considerando o público idoso com baixa visão. Com base nas recomendações propostas na legislação brasileira, os autores pontuam os principais aspectos tipográficos presentes nas tabelas e os desafios para atender as necessidades informacionais desse público.

A inclusão se faz presente também no contexto educacional. A diminuição das barreiras informacionais e interacionais em jogos educacionais digitais é apresentada por Cezarotto e Chamberlin. A partir da multimodalidade, os autores propõem um framework para desenvolvimento de jogos acessíveis considerando os diferentes espectros das deficiências.

A compreensão sobre a estrutura sintática e semântica da representação gráfica de processos é apresentada na pesquisa de iniciação científica de Damacena e Smythe. As autoras identificam os componentes gráficos e as relações entre eles, a partir da análise de diferentes representações, destacando sua relevância para a compreensão de fluxos informacionais, recorrentes em métodos e processos.

Parabenizamos os artigos selecionados e desejamos uma boa leitura!

Kelli C. A. S. Smythe e Rafael de Castro Andrade presidente e vice-presidente do comitê científico CIDI + CONGIC 2021 